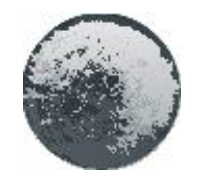

\title{
MOVIES IN NATURAL SCIENCE EDUCATION: NEW TRENDS
}

\author{
Vanessa Mendes Carrera, Agnaldo Arroio \\ University of Sao Paulo, Faculty of Education, Brazil
}

\begin{abstract}
Media have played a relevant role in society because it is through them that values and concepts of our time are incorporated by teenagers and children. It is important to understand these effects as the young generation is exposed to these media and also how it would be possible to take advantage of this influence to school practices. Focused on this issue, the influence of media, in special movies, how the research in science education had been studies this trend. These work it is an art state which focuses on understands how and what kind of research related with this issue in Natural Science Education in Brazil. For this, we used the full papers presented at the ENPEC-Brazilian Conference on Research in Science Education from 1997 (date of the first meeting) to 2009 (the recently). It is expected that this knowledge will allow evaluating and redirecting these educational researches related to this issue based on our results with the theme cinema and education.
\end{abstract}

Key words: education and media, movies, natural science education, trends.

\section{Introduction}

Media has a great influence and could be considered as a part of the lives of new generation of Brazilian society. Studies of the National Panel Television - IBOPE, that measure hearing in Brazilian cities show the time that youngsters spend in front of television per day; it is even longer than the time they spent in school. This consumption is not limited to broadcast television, but the pay-per-view TV, and DVDs. Commercial Movies, focus of this work, are included in these categories. Studies also revealed that the mixing of sound, word and image create a receipt_because it causes sensations that stimulate the perception by using different languages (verbal, gestural, visual)_involving people with the subject, producing meaning and, thus, ensuring the understanding of the message.

Regarding the use of movies for teaching natural science_it is known that this education has as main feature the need to place the student in contact with the object studied through experimentation, observation and creation of hypotheses about its processes (Bizzo, 2001). Unfortunately, due to lack of material, space or time, it is not always that students can have this practical experience in their learning and as movies can transcend time and space variables, it is common to bring in their contents exemplifications of situations that students have no opportunity to witness in the classroom. This makes the movies an educational resource of great efficiency. Not only educational movies can be used in schools, which ones that are intended for entertainment can be more attractive to your audience ensuring the transmission of the message (Arroio, 2007).

As it is a trend of research that is new, it was noticed that some research lines are concentrated in one area and little explored in another._Given this situation, this work is an art state on the use of commercial movies into the Natural Science Education in Brazil. 
On this sense, this work aims to establish an overview based on state of art about this issue to contribute on the development of this field research related to this issue.

\section{Methodology of Research}

The research method used was the Art State as Megid Neto and Pacheco (2001) consider this type of research as a field of studies which examine full paper in an attempt to establish features such as: historical developments, trends and methodological issues, the main results of the investigations, problems and limitations, gaps and unexplored research fields, between many other aspects that should be the object of analysis related to academic research in a particular field of research.

The Art State has qualitative and quantitative characteristics in order to promote a unified search of knowledge. By promoting this analysis it is possible to obtain an overview of the issue in focus, so it chances to perform critical review of studies and research and disseminate it to society.

On this way, full paper present on the last decade since form the first edition of the conference ENPEC -Brazilian Conference in Research on Science Education, in 1997 until the last edition 2009, it means 6 edition of this biannual conference organized by ABRAPEC - Brazilian Association on Research in Natural Science Education. All these papers were analyzed considering some key-words as audiovisual, movies, films, video, and cinema and then the selected papers were categorized according to this descriptor below.

For the selection of the material it was used the ENPEC Proceedings in which the full papers were read one by one. In order to minimize potential failures at this stage, it was necessary to select the material in a comprehensive way. Thus, with the material preselected extended, we may assume for the complete reading of full paper more accurately assessing their consistency in this study.

To define the appropriate methodology, it was noticed on previous studies that also have this character (Megid, 1999; Queiroz, Francisco, 2005; Francalanza, 1993; Serra, 2009) outlining some parameters to be considered as descriptors. They allow arranging full papers according to this established descriptor in some categories:

- Year of publication (from 1997 until 2009)

- Local publications (Geographic Region of Brazil)

- Thematic focus ( In-service teacher training / Teaching and Learning / Language and Cognition/ Formal and Non-Formal Education / Public Policies / Other)

- School level (Upbringing / Elementary School I / Elementary School II / High School / University / Pre-service teacher training / General)

- Area of concentration (Environmental Education / Health / Chemistry / Physics / Biology / Other).

\section{Results of Research}

During the selection of the material it has been taken care in maintaining the focus of research concerns the use of commercial movies related to teaching and learning Natural Science Education. Therefore, it was not considered any full paper that would address technical videos or educational movies, documentaries, newscasts, soap operas and serials. 


\section{Publication Year}

The total number of full papers published in the seven editions of ENPEC Proceedings from 1997 to 2009 was 3470 full papers. Only six full papers were selected that addressed the topic of the research on using movies in Natural Science teaching and learning. The selected papers were distributed by year of presentation and compared to the all papers of the event. As it is presented in Table 1.

Table 1. Distribution of full papers published in ENPEC 1997 to 2009, according to the year of presentation and comparison with the number of papers in the same period.

\begin{tabular}{|c|c|c|c|c|c|c|c|c|}
\hline ENPEC & $\begin{array}{c}\text { 1th } \\
\mathbf{1 9 9 7}\end{array}$ & $\begin{array}{c}\mathbf{2 t h} \\
\mathbf{1 9 9 9}\end{array}$ & $\begin{array}{c}\text { 3th } \\
\mathbf{2 0 0 1}\end{array}$ & $\begin{array}{c}\mathbf{4 t h} \\
\mathbf{2 0 0 3}\end{array}$ & $\begin{array}{c}\text { 5th } \\
\mathbf{2 0 0 5}\end{array}$ & $\begin{array}{c}\text { 6th } \\
\mathbf{2 0 0 7}\end{array}$ & $\begin{array}{c}\text { 7th } \\
\mathbf{2 0 0 9}\end{array}$ & TOTAL \\
\hline $\begin{array}{c}\text { Works } \\
\text { presented }\end{array}$ & 128 & 163 & 233 & 451 & 738 & 958 & 799 & 3470 \\
\hline $\begin{array}{c}\text { Selected } \\
\text { works }\end{array}$ & 0 & 0 & 0 & 0 & 3 & 0 & 3 & 6 \\
\hline
\end{tabular}

Although the number of presentations at the event has increased there is no linearity or results that indicate these studies with the use of movies in natural science education are also increasing. It can be noticed it is signs concentrated in two distinct and relatively current.

During the selection of papers it is clear that in the first meetings of the event, video was used to record interventions in the classroom as a self-assessment. After, although there is a predominance of educational videos, some are already using commercial movies with the goal of doing a critical reading, but the analysis is given in the sociological and philosophical field, being excluded from the study. At 5 th and 7 th ENPEC were selected in each one three studies that fit with the theme of this research. They will be better described and discussed below.

\section{Geographic Location of Production}

In the Table 2, it is possible to see from which region of Brazil that these full papers were done.

Table 2. Distribution of selected full papers presented in ENPEC 1997 to 2009, according to the geographical regions of Brazil and by year.

\begin{tabular}{|c|c|c|c|c|c|c|c|c|}
\hline ENPEC & $\begin{array}{c}\text { 1th } \\
1997\end{array}$ & $\begin{array}{c}\text { 2th } \\
1999\end{array}$ & $\begin{array}{c}\text { 3th } \\
2001\end{array}$ & $\begin{array}{c}\text { 4th } \\
2003\end{array}$ & $\begin{array}{c}\text { 5th } \\
2005\end{array}$ & $\begin{array}{c}\text { 6th } \\
2007\end{array}$ & $\begin{array}{c}7 \text { th } \\
2009\end{array}$ & TOTAL \\
\hline North & & & & & & & & 0 \\
\hline Northeast & & & & & & & & 0 \\
\hline South & & & & & & & & 0 \\
\hline Southeast & & & & & 3 & & 3 & 6 \\
\hline Midwest & & & & & & & & 0 \\
\hline
\end{tabular}


All of them are from the Southeast region in Brazil. These full papers of the 5 th ENPEC, one it is from Rio de Janeiro-UERJ, and the other two are from São Paulo, one of the Universidade Cruzeiro do Sul and other from Universidade de São Paulo- USP. On the 7th ENPEC the three papers are from the Universidade de São Paulo -USP.

As the first five editions of ENPEC have occurred in the southeast and the latter two in the south, maybe the distance between some regions of Brazil could be an impeditive for researchers moving to present their papers.

\section{Thematic Focus}

Taking into account the descriptors detailed in the methodology of the papers selected were classified as shown in Table 3.

Table 3. Distribution of selected papers in ENPEC 1997 to 2009, according to the main thematic focus.

\begin{tabular}{|c|c|c|c|c|c|c|c|c|}
\hline ENPEC & $\mathbf{1 t h}$ & $\mathbf{2 t h}$ & $\mathbf{3 t h}$ & $\mathbf{4 t h}$ & $\mathbf{5 t h}$ & $\mathbf{6 t h}$ & $\mathbf{7 t h}$ & TOTAL \\
\hline $\begin{array}{c}\text { In-service } \\
\text { teacher } \\
\text { training }\end{array}$ & $\mathbf{1 9 9 9}$ & $\mathbf{2 0 0 1}$ & $\mathbf{2 0 0 3}$ & $\mathbf{2 0 0 5}$ & $\mathbf{2 0 0 7}$ & $\mathbf{2 0 0 9}$ & \\
\hline $\begin{array}{c}\text { Teaching } \\
\text { and learning }\end{array}$ & & & & & 1 & & & 1 \\
\hline $\begin{array}{c}\text { Language } \\
\text { and } \\
\text { cognition }\end{array}$ & & & & 1 & & 1 & 2 \\
\hline $\begin{array}{c}\text { Formal and } \\
\text { Non-formal } \\
\text { Education }\end{array}$ & & & & & & 1 & 1 \\
\hline $\begin{array}{c}\text { Public } \\
\text { Policies }\end{array}$ & & & & & & & & 0 \\
\hline Other & & & & & & 1 & 1 \\
\hline
\end{tabular}

In In-service Teacher Training categories it was found: “A utilização do video educativo como possibilidade de domínio da linguagem audiovisual pelo professor de ciências" (Arroio; Diniz; Giordan, 2005) that refers to a survey of a group of Science teachers from high school during an in service education program. In this program were discussed concepts related to the reading of videos and they had to plan activities for teaching that used video as a tool. This title has raised questions as to consider the paper because it used the term "educational video". It was noticed that the focus of the work took place in the use of an audiovisual toll in general to discuss the audiovisual language and its relation to in-service teacher training and the fact of having been chosen educational video was a fluke and not the goal.

At the Teaching and Learning categories it were found: "O ensino de Ciências através do cinema"'(Santos, 2005)_which describes the movie as a tool for natural science education using the socio-interactionist approach proposed by Vygotsky that a viewer can interact with the characters and take ownership of a natural science education through 
their everyday situations depicted in a movie. To address the issue of pollution and its environmental consequences using the movie 'The Day After Tomorrow "(U.S., 2004) and, for the subject turned to the subject of drugs and side effects of drug use: "Barbarian Invasions" (Canada / France, 2003).

Thematic focus in Language and Cognition it were found two papers, the first "Alternativas didáticas: uma proposta para o ensino de Química Nuclear" (Figueira, 2005) and: "Ficção científica nas aulas de ciências: filmes, romances e contos em contraste" (Piassi, 2009). Both are compared in various languages used in teaching, including the movie. The authors stress that the commercial movie are the result of interpreting the world and they carry some mistakes because that is the scientific social knowledge about that subject. They also reflect on strengths and difficulties in using this language in the classroom.

In Formal and Non-formal Education it were found: "Argumentação científica em um filme infanto-juvenil e na escrita dos alunos: uma relação possível?" (Assem; Trivelato, 2009) which is a research based on experimentation and documentation of an event occurring with students in the 5th year of elementary school. The research assumes that learning is an activity where there is the interaction between visual communication, language and actions and, therefore, students select different semiotic modes such as is provided by the visual aid.

In other paper: "A utilização de recursos audiovisuais no ensino de ciências: tendências nos ENPECs entre 1997 e 2007' (Santos; Arroio, 2009) it is a Art State about audiovisual resources.

\section{School Level}

To understand in which level of school they were addressed was elaborated in Table 4.

Table 4. Distribution of selected articles presented in ENPEC 1997 to 2009, according to grade level by year of presentation.

\begin{tabular}{|c|c|c|c|c|c|c|c|c|}
\hline ENPEC & $\begin{array}{c}\text { 1th } \\
\mathbf{1 9 9 7}\end{array}$ & $\begin{array}{c}\mathbf{2 t h} \\
\mathbf{1 9 9 9}\end{array}$ & $\begin{array}{c}\text { 3th } \\
\mathbf{2 0 0 1}\end{array}$ & $\begin{array}{c}\text { 4th } \\
\mathbf{2 0 0 3}\end{array}$ & $\begin{array}{c}\mathbf{5 t h} \\
\mathbf{2 0 0 5}\end{array}$ & $\begin{array}{c}\text { 6th } \\
\mathbf{2 0 0 7}\end{array}$ & $\begin{array}{c}\mathbf{7 t h} \\
\mathbf{2 0 0 9}\end{array}$ & TOTAL \\
\hline Level & $\mathbf{U}$ & & & & & & & 0 \\
\hline $\begin{array}{c}\text { Elementary } \\
\text { School I }\end{array}$ & & & & & & & 1 & 1 \\
\hline $\begin{array}{c}\text { Elementary } \\
\text { school II }\end{array}$ & & & & & & & & 0 \\
\hline High School & & & & & & & & 0 \\
\hline Universities & & & & & & & & 0 \\
\hline Teacher & & & & & 1 & & & 1 \\
\hline General & & & & & 2 & & 2 & 4 \\
\hline
\end{tabular}

In Elementary school I category is: "Argumentação científica em um filme infanto-juvenil e na escrita dos alunos: uma relação possível?" (Assem; Trivelato, 2009). In this paper, using the benchmark of Stephen Toulmin, it attempted to analyze the construction of scientific arguments based on the proposal of a production activity written on the commercial movie 'Over the Hedge' (U.S., 2006). It was assisted with students of 
9-10 years old from a private school in São Paulo. It was found that the information conveyed by this visual aid is internalized and produce meaning.

On the level Teacher training: "A utilização do vídeo educativo como possibilidade de domínio da linguagem audiovisual pelo professor de ciências" (Arroio; Diniz, Giordan, 2005). This paper is about an in-service training education program offered to a group of public school teachers (Chemistry, Physics, and Biology) of high school. Its intention was to provoke discussion of concepts related to reading videos for the appropriation of the audiovisual language.

In the work: "O ensino de Ciências através do cinema" (Santos, 2005), for example, it was chosen movies that addressed social issues like the pollution and the effects of human interference with the environment through the movie 'The Day After Tomorrow "(U.S., 2004). Another issue is related to drug use in relation to drug addiction and its use as medicine in the movie 'Barbarian Invasions "(Canada / France, 2003). Given the concern in establishing a social dialogue involving issues like the environment and drugs, believed to be the target audience of teenagers, which corresponds to the last year of Elementary School and High School. In: "Alternativas didáticas: uma proposta para o ensino de Química Nuclear" (Figueira, 2005) the author makes clear the initiative to offer young people opportunities to learn through different languages. Whereas the Statute of Children and Adolescents (Law No. 8069 of July 13, 1990) includes in its Title I, Article 2 that adolescent are those between twelve and eighteen years of age, and that the PCN - National Guidelines Curriculum introduce Chemistry contents in the last years of Elementary School and High School, we can conclude that this work aims if the public Elementary School II and High School.

On the paper: "A utilização de recursos audiovisuais no ensino de ciências: tendências nos ENPECs entre 1997 e 2007” (Arroio; Santos, 2009) this is an art state of audiovisual resources as they have being used. Finally in: "Ficção científica nas aulas de ciências: filmes, romances e contos em contraste" (Piassi, 2009) the author makes clear the intention to treat the physics content and, being physical content for the last years from elementary and high school, it seems that is its focus.

\section{Concentration Area}

Here the distributions of selected papers from the area that is intended.

Table 5. Distribution of selected papers presented in ENPEC 1997 to 2009, according to the corresponding area of concentration.

\begin{tabular}{|c|c|c|c|c|c|c|c|c|}
\hline ENPEC & $\begin{array}{c}\text { 1th } \\
\mathbf{1 9 9 7}\end{array}$ & $\begin{array}{c}\mathbf{2 t h} \\
\mathbf{1 9 9 9}\end{array}$ & $\begin{array}{c}\text { 3th } \\
\mathbf{2 0 0 1}\end{array}$ & $\begin{array}{c}\mathbf{4 t h} \\
\mathbf{2 0 0 3}\end{array}$ & $\begin{array}{c}\mathbf{5 t h} \\
\mathbf{2 0 0 5}\end{array}$ & $\begin{array}{c}\mathbf{6 t h} \\
\mathbf{2 0 0 7}\end{array}$ & $\begin{array}{c}\text { 7th } \\
\mathbf{2 0 0 9}\end{array}$ & TOTAL \\
\hline $\begin{array}{c}\text { Environmental } \\
\text { Education }\end{array}$ & & & & & & & 1 & 1 \\
\hline Health & & & & & & & & 0 \\
\hline Chemistry & & & & & 2 & & & 2 \\
\hline Physics & & & & & & & 1 & 1 \\
\hline Biology & & & & & & & & 0 \\
\hline Other & & & & & 1 & & 1 & 2 \\
\hline
\end{tabular}


For these three articles from the 5th ENPEC it was found two studies related to chemistry: the first in its relationship with pollution and drugs (Santos, 2005) and the second, associated with nuclear chemistry (Figueira, 2005). In the third (Arroio; Diniz; Giordan, 2005) it is known that the group of teachers who participated in the survey is heterogeneous (chemistry, physics, biology and science) so the face of this variety was preferred to include it other.

On the 7th ENPEC, of the three works, one belongs to the category other (Santos; Arroio, 2009), because it uses science so comprehensive in its collection for a descriptive art state, the second refers to the use of physics in space (Piassi, 2009) and, finally, comes to environmental issues (Assem; Trivelato, 2009).

\section{Discussion}

Analyzing the tables it is possible notice a lack of works relating to areas such as Health and Biology. The largest concentration is in the areas Chemistry, Physics and Environment._Perhaps, because Chemistry and Physics have a complex content, researchers notice that the movie could bring until the students situations that they could compare to their life, and it facilitates the learning. About the environment it is important show how our activities can influence the world and movies depict this well.

With regard to the school level, considering the General category, realize that the greatest concentration of work takes place in high school and Elementary school II perhaps because of the intention of capturing the attention of teenagers from situations in which they are interested and this is a good signal, however, in upbringing and elementary school I it is very important of playful use of imagination and the ability to show through images in movement situations that they have never met and would be difficult to imagine themselves.

Therefore, it is believed that the field of use of commercial movies for the teaching and learning natural science still needs to face some prejudices and establish itself in the face of current methodologies. There is a growing number of studies using technological resources and movies, but just few refers to the teaching and learning natural science should be further explored considering and areas of activity mentioned above.

\section{Conclusion}

It is possible to conclude that the amount of full papers that address the issue of using commercial movies into teaching and learning in Natural Science Education is very small given the large concentration of papers in the event. This may be related to two factors: The first refers to prejudice the use of commercial movies for teaching. There is a predominance of educational videos with the argument that these resources do not have mistakes in their content, this suggests that education professionals and society in general still are not prepared to deal with audiovisual languages and with the need to start from the standpoint of the student to produce knowledge, which is often misleading because of social beliefs. So it is considered easier and more assertive use an educational movie.

The second relates to the fact of having more work involving commercial movies for discussion in the field of history, philosophy, anthropology and other social and cultural manifestations. In these movies we can analyze the behavior of the characters, discuss ethical issues and reflect on the existing modernities, proving that this is important in school today. This demonstrates that the film is a good agent raised the questions and 
reflections, but with refers to the contents of Science, the number of papers drop to less than half.

\section{References}

Arroio, A. (2007). The role of cinema into science education. Problems of Education in the 21 st Century (Science Education in a Changing Society), Vol. 1, p. 25-30.

Arroio, A., Diniz, M., Giordan, M. (2005). A utilização do vídeo educativo como possibilidade de domínio da linguagem audiovisual pelo professor de ciências. $V$ - Encontro $\mathrm{Na}$ cional de Pesquisa em Educação em Ciências - VENPEC - ATAS. Bauru, ABRAPEC.

Assem, E., Trivelato, S. (2009). Argumentação científica em um filme infanto-juvenil e na escrita dos alunos: uma relação possível? VII- Encontro Nacional de Pesquisa em Educação em Ciências - VI ENPEC - ATAS. Florianópolis, ABRAPEC.

Bizzo, N. (2001). Ciências: fácil ou difícil? São Paulo: Ática.

Brasil (1998). Ministério da Educação e do Desporto. Parâmetros Curriculares Nacionais. Brasília: MEC/SEF.

Figueira, R. (2005). Alternativas didáticas: uma proposta para o ensino de Química Nuclear. V-Encontro Nacional de Pesquisa em Educação em Ciências - V ENPEC - ATAS. Bauru, ABRAPEC.

Fracalanza, H. (1993). O que sabemos para livros didáticos para o ensino de Ciências no Brasil (Tese de doutorado, Universidade Estadual de Campinas - Faculdade de Educação, 1993).

Megid Neto, J. (1999). Tendências da pesquisa acadêmica sobre o ensino de Ciências no nível fundamental (Tese de doutorado, Universidade Estadual de Campinas - Faculdade de Educação, 1999).

Megid Neto, J., Pacheco, D. (2001) Pesquisas sobre o ensino de Física no nível médio no Brasil: concepção e tratamento de problemas em teses e dissertações. In: Nardi, R., Pesquisas em ensino de Física. São Paulo: Escrituras. p. 15-30.

Piassi, L. (2009). Ficção científica nas aulas de ciências: filmes, romances e contos em contraste. VII- Encontro Nacional de Pesquisa em Educação em Ciências - VI ENPEC ATAS. Florianópolis, ABRAPEC.

Queiroz, S. L., Francisco, C. A. (2005). Análise dos trabalhos apresentados nos encontros de debates sobre o ensino de química de 1999 a 2003. V Encontro Nacional de Pesquisa em Ensino de Ciências - V ENPEC - ATAS. Bauru, ABRAPEC.

Santos, N. (2005). O ensino de Ciências através do cinema. $V$ - Encontro Nacional de Pesquisa em Educação em Ciências - V ENPEC - ATAS. Bauru, ABRAPEC.

Santos, P., Arroio, A. (2009). A utilização de recursos audiovisuais no ensino de ciências: tendências nos ENPECs entre 1997 e 2007. VII- Encontro Nacional de Pesquisa em Educação em Ciências - V ENPEC - ATAS. Florianópolis, ABRAPEC.

Serra, G. M. D. (2009). Contribuição das TIC no ensino e aprendizagem de Ciências: tendências e desafios (Dissertação de mestrado, Universidade de São Paulo - Faculdade de Educação, 2009).

Received 20 May 2011; accepted 30 October 2011

\section{\begin{tabular}{ll}
\hline \\
\end{tabular}}

Researcher, Faculty of Education, University of Sao Paulo, Av. da Universidade 308, 05508-040, São Paulo Brazil.

E-mail: vanessa.carrera@usp.br

Website: http://www.usp.br/

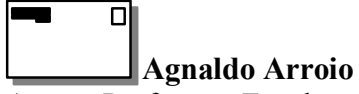

Assoc. Professor, Faculty of Education, University of Sao Paulo, Av. da Universidade 308, 05508-040, São Paulo Brazil.

E-mail: agnaldoarroio@yahoo.com Website: http://www.usp.br/ 